\title{
sciendo
}

\author{
IWONA LISOWSKA ${ }^{1}$, MAGDALENA LEWICKA², MAGDALENA SULIMA², WERONIKA TOPYŁA ${ }^{3}$, \\ DOMINIK RUTA ${ }^{3}$, ARTUR WDOWIAK ${ }^{3}$
}

\section{Assessment of the severity of the stress levels of women in childbirth}

\begin{abstract}
Introduction. It is well known that the period of maternity commencing from conception is accompanied by great emotions. Each stage is associated with specific behavior as well as the anxiety. The postpartum period is particularly exposed to stress and the ability to overcome it is very important, therefore the support of the loved ones is necessary.

Aim. Assessment of the severity of the stress levels of women in childbirth.

Material and methods. The research was conducted among 178 women during the postpartum period. The methods of diagnostic survey and own questionnaires were used, as well as PSS-10 standardized tool.

Results. The study involved 178 women during the postpartum period. Interpretation of results for the level of stent PSS-10 showed low results $-23.6 \%$, average $-32.6 \%$, high $-43.8 \%$ due to a high stress level. Statistically significant factors are: marital status - married women experience lower stress levels, socioeconomic status - the higher socioeconomic status, the test group felt lower stress, birth time - there is a significant difference between women giving birth before 37 weeks and those giving birth in right term. Particular age group, place of residence, education, the number of births and the way of birth are not factors that differentiate levels of perceived stress of women in childbirth.

Conclusions. Perinatal period is a time of dynamic changes characterized by high levels of stress. Age, place of residence, education, number of births and way of birth do not affect the level of stress, whereas marital status, socioeconomic situation and the date of birth determine stress levels for women.
\end{abstract}

Keywords: childbirth, stress, education.

DOI: $10.2478 /$ pjph-2018-0001

\section{INTRODUCTION}

Motherhood is not a purely biological process of delivering the child into the world. It is not also the fulfillment of educational functions predetermined by the community. Child's conception and birth are a huge change in a woman's life. The fact of being pregnant can cause stress, despair, fear of the future or joy, which are reinforced by hormonal and anatomical changes. This is often a range of cyclically changing emotions constantly accompanying mother during pregnancy and maternity. New role, new family member who requires constant attention and care, tiredness and hormones create a combination that significantly burden/load the body and the psyche of the mother [1-4].

Media create a perfect motherhood's picture. The feeling of constant pressure can cause stress and depression in women $[3,5,6]$. Continuous and sustained stress load leads to the occurrence of somatic and mental disorders, such as recurrent headaches, trembling hands and feet, increased muscle tension, increase of blunt and shallow breathing, tics, palpitations, excessive sweating, difficulty concentrating, insomnia, fatigue, irritability. Often, resistance decreases and there appear hyperactivity, aggressive behavior, withdrawal, apathy or depression. [1,7-9].

To prevent the psychological consequences, every woman should learn to cope with stress. A preferable style in childbirth is the style focused on the tasks. Women then focus not on the stressful factor but specific assignment for example, childcare or breastfeeding $[8,10]$. Good way to relieve tension and stress is physical exertion or autogenous training, which is a form of relaxation $[7,11]$.

To relieve mother's stress, there is a need of support from the family. In situations when relatives' and friends' support is not enough, mother should go to a specialist, for example psychologist, to help solve the problem and learn how to handle with stress $[1,7,12]$.

\section{AIM}

The purpose of the scientific research was the assessment of the severity of the women's stress level.

\footnotetext{
${ }^{1}$ A graduate of obstetrics, Faculty of Health Sciences, Medical University of Lublin, Poland

2 Department of Obstetrics, Gynaecology and Obstetrical-Gynaecological Nursing, Faculty of Health Sciences, Medical University of Lublin, Poland

${ }^{3}$ Diagnostic Techniques Unit, Medical University of Lublin, Poland
} 


\section{MATERIAL AND METHODS}

Scientific research was carried out among 178 women during the postpartum period, in Krosno. Among the respondents, the most numerous group were women aged 18-25 years old $(30.3 \%)$. Analyzing the place of residence, it was noticed that $63.5 \%(n=113)$ of women in childbirth inhabit urban area and $36.5 \%(n=65)$ live in the village. The least number of mothers had basic education $-18.0 \%$, secondary education $-40.4 \%$ and university education $-41.6 \%$. Married women accounted $69.1 \%$ of the group. Newly delivered mothers who determined their socioeconomic status as good are the largest group 46.1\%. Primiparas accounted for $55.6 \%$ i.e. 99 respondents. The largest number of women (68.5\%) delivered in right time. In the test group, the percentage of births by caesarean section was high and represented up to $39.3 \%$ (70 people).

In the scientific research we used the method of diagnostic survey. The research had a form of the questionnaire concerning the characteristics of the study group and standardized tool PSS-10 was used. Statistical analysis was made using 10.0 Statistica (StatSoft, Inc., 2011). The normal distributions for the two scoring systems was verified by the Shapiro-Wilk and the homogeneity of variance was verified by using Levene's test. The variables satisfy the assumptions regarding the use of parametric methods of statistical hypothesis and verification was carried out by using correlation coefficient $r$ Pearson's, test $t$ (Student) for independent variables and one-way analysis of variance (with post-hoc test Tukey HSD). The significance level was assumed to be $p=0.05$. Statistical results were regarded significant when enumerated test $\mathrm{p}$ plausibility fulfilled inequality $\mathrm{p}<0.05$.

\section{RESULTS}

TABLE 1. Results of the transformation units standardized in sten scores PSS 10.

\begin{tabular}{|c|c|c|}
\hline Sten & Number & Percent \\
\hline 1 & 0 & 0.0 \\
\hline 2 & 3 & 1.7 \\
\hline 3 & 17 & 9.6 \\
\hline 4 & 22 & 12.4 \\
\hline 5 & 25 & 14.0 \\
\hline 6 & 33 & 18.5 \\
\hline 7 & 32 & 18.0 \\
\hline 8 & 28 & 15.7 \\
\hline 9 & 11 & 6.2 \\
\hline 10 & 7 & 3.9 \\
\hline Together & 178 & 100 \\
\hline
\end{tabular}

Interpretation: sten 1-4: low results, sten 5-6: mediocre results, sten 7-10: high scores

TABLE 2. Interpretation level of result in the sten scores PSS-10.

\begin{tabular}{lcc}
\hline \hline \multicolumn{1}{c}{ PSS 10 } & Number & Percent \\
\hline low results & 42 & 23.6 \\
\hline average results & 58 & 32.6 \\
\hline high scores & 78 & 43.8 \\
\hline Together & 178 & 100 \\
\hline
\end{tabular}

Table 2 presents the level of stress of a standardized tool PSS-10. The low results were obtained by $23.6 \%$ of respondents (42 people), the average results by $32.6 \%$ (58 people), while $43.8 \%$ ( 78 people) received high scores, which is associated with the feeling of high stress.

TABLE 3. Correlation between sociodemographic factors and the level of perceived stress (PSS-10).

\begin{tabular}{|c|c|c|c|c|c|}
\hline Age & Average & $\mathbf{N}$ & SD & $\mathbf{F}$ & $\mathbf{p}$ \\
\hline up to 25 years & 18.87097 & 62 & 7.280074 & \multirow{4}{*}{0.8690} & \multirow{4}{*}{0.458} \\
\hline $26-30$ years & 16.89583 & 48 & 6.491368 & & \\
\hline $31-40$ years & 18.58140 & 43 & 6.344223 & & \\
\hline Over 40 years & 17.88000 & 25 & 6.247133 & & \\
\hline Place of residence & Average & $\mathbf{N}$ & SD & $\mathbf{t}$ & $\mathbf{p}$ \\
\hline City & 17.92035 & 113 & 7.014197 & \multirow{2}{*}{-0.5468} & \multirow{2}{*}{0.585} \\
\hline Village & 18.49231 & 65 & 6.167260 & & \\
\hline Education & Average & $\mathbf{N}$ & SD & $\mathbf{F}$ & $\mathbf{P}$ \\
\hline Professional & 20.34375 & 32 & 8.134393 & \multirow{3}{*}{2.303960} & \multirow{3}{*}{0.103} \\
\hline Secondary & 17.94444 & 72 & 6.025507 & & \\
\hline University & 17.35135 & 74 & 6.542658 & & \\
\hline Marital status & Average & $\mathbf{N}$ & SD & $\mathbf{t}$ & $\mathbf{p}$ \\
\hline Married & 17.43089 & 123 & 6.254285 & \multirow{2}{*}{2.09774} & \multirow{2}{*}{0.037} \\
\hline Unmarried & 19.69091 & 55 & 7.443299 & & \\
\hline Socioeconomic status & Average & $\mathbf{N}$ & SD & $\mathbf{F}$ & $\mathbf{p}$ \\
\hline Insufficient or average & 19.23881 & 67 & 7.109724 & \multirow{3}{*}{4.26344} & \multirow{3}{*}{0.016} \\
\hline Good & 18.32927 & 82 & 5.843758 & & \\
\hline Very good & 15.00000 & 29 & 7.285014 & & \\
\hline
\end{tabular}

One-way analysis of variance which was carried out did not show any differences between age groups in women during childbirth $(\mathrm{F}=0.8690, \mathrm{p}=0.458)$. This means that age group affiliation is not a factor which significantly grade levels of perceived stress in women during childbirth. Also, the analysis which was carried out using test $t$ (Student) for the independent variables has not showed any statistically significant differences between the groups for differentiating patients residence $(\mathrm{t}=4.3 ; \mathrm{p}=0.000)$. It turns out that women inhabiting the village and urban areas feel the stress on a similar level. Also, education is not a factor that significantly grade levels of perceived stress in women during childbirth $(\mathrm{F}=2.3039, \mathrm{p}=0.103)$. The analysis carried out, which was made using test $\mathrm{t}$ (Student) for the independent variables showed the existence of significant differences between the groups of unmarried and married women $(\mathrm{t}=2.098, \mathrm{p}=0.037)$. It turns out that married women experience lower stress levels than single women.

The one-way analysis of variance showed the existence of differences between the socioeconomic situation and the level of stress $(\mathrm{F}=4.2634, \mathrm{p}=0.016)$. This means that socioeconomic status is a factor that significantly differentiates the level of perceived stress in women during childbirth. It has been proved that the higher socioeconomic status is, the lower stress level is experienced by women. The analysis of the post-hoc using Tukey HSD test revealed that significant differences exist between the group of women with insufficient or average and very good socioeconomic status $(p=0.038)$. Between women with insufficient or average and good socioeconomic status $(p=0.703)$, and very good status $(p=0.132)$, no significant differences were noticed. 
TABLE 4. The correlation between obstetric situation and the level of perceived stress (PSS-10).

\begin{tabular}{|c|c|c|c|c|c|}
\hline Number of births & Average & $\mathbf{N}$ & SD & $\mathbf{F}$ & $\mathbf{p}$ \\
\hline Primipara & 18.89899 & 99 & 6.731733 & \multirow{2}{*}{1.7241} & \multirow{2}{*}{0.086} \\
\hline Multipara & 17.16456 & 79 & 6.587538 & & \\
\hline Time of giving birth & Average & $\mathbf{N}$ & SD & $\mathbf{t}$ & $\mathbf{p}$ \\
\hline $\begin{array}{l}\text { up to } 37 \text { weeks } \\
\text { pregnancy }\end{array}$ & 20.75610 & 41 & 6.011574 & \multirow{3}{*}{8.6015} & \multirow{3}{*}{0.000} \\
\hline $38-42$ week pregnancy & 16.78689 & 122 & 6.564656 & & \\
\hline $\begin{array}{l}\text { After } 42 \text { weeks of } \\
\text { pregnancy }\end{array}$ & 21.86667 & 15 & 6.468237 & & \\
\hline The way of birth & Average & $\mathbf{N}$ & SD & $\mathbf{F}$ & $\mathbf{p}$ \\
\hline Physiological birth & 17.59259 & 108 & 6.947113 & \multirow{2}{*}{-1.3291} & \multirow{2}{*}{0.186} \\
\hline Cesarean section & 18.95714 & 70 & 6.272636 & & \\
\hline
\end{tabular}

The analysis, which was carried out using test $\mathrm{t}$ (Student) for the independent variables has not revealed any statistically significant differences between the number of deliveries and the level of stress in the postpartum period $(\mathrm{F}=1.7241$, $\mathrm{p}=0.086$ ). A method of termination of pregnancy has not affected the level of stress in the postpartum period $(\mathrm{F}=-1.3291$, $\mathrm{p}=0.186$ ).

The one-way analysis of variance showed that the time of birth is a factor which significantly differentiates the level of perceived stress among women during childbirth $(\mathrm{F}=8.6015$, $\mathrm{p}=0.000$ ). A post-hoc analysis, which was conducted using the Tukey HSD test revealed that significant differences exist between the group of women who gave birth before $37^{\text {th }}$ week of pregnancy, and those who delivered in the right period $38-42$ week of pregnancy $(p=0.015)$. There weren't noticed any significant differences between women who gave birth before and after the due date -42 week of pregnancy $(\mathrm{p}=0.884)$, and between delivery on time and those who delivered child after $42^{\text {nd }}$ week of pregnancy $(\mathrm{p}=0.778)$.

\section{DISCUSSION}

Perinatal period is a time of dynamic changes in a woman. Many authors emphasize that the expecting of childbirth and pregnancy cause a lot of emotions intensified by adaptive anatomical and hormonal changes $[4,13,14]$. It should be highlighted that stress during childbirth is reinforced by the new situation in life, finding women faced with the challenge of responsibility for the child and the problems posed by the postpartum period.

The results of own research has confirmed high levels of perceived stress in women during childbirth, measured according to the scale PSS 10 . Only 42 (23.6\%) of 178 women were characterized by a low level of stress. It is consistent with the Kowalska J. et al. results [14], where the perceptible stress did not have low level and also conditioned the mood during the first 8 weeks postpartum. Chaaya [15] and Cheng Pickler [10] have also stated that women during childbirth are characterized by high levels of stress, much higher than the general population of women.

The effectiveness of the research tool PSS-10 has been confirmed in many previous studies. Chaaya et al. [15] compared the efficacy of this magnitude with the scale GHQ 12 and EPDS in Arabic women in pregnancy and puerperium, demonstrating the results which also showed that the PSS-10 [16] was more specifically characterized by the level of stress in a greater number of respondents people.
Many authors in the literature emphasizes that the level of stress is influenced by many factors. Kowalska J. et al. [14] reported that the marital status has an appreciable impact on stress. Women in civil partnership feel much lower stress levels than single women. In their studies, age and education of surveyed women did not have any significant impact on the perceived level of stress. In our research, Kossakowska's results were confirmed on the effects of civil status, because it turned out that married women experience lower stress levels than single women. Also, our study did not show any significant effect of age and education of the respondents group on the felt stress. Similarly, it was turned out that the place of residence have no impact on the level of stress. Piech et al. [17] found that the place of residence has an influence on the sense of anxiety and stress in women in childbirth. Higher intensity of anxiety was characterized by residents living in the village.

The results of our own research showed that socioeconomic status has a significant impact on the level of stress in the childbirth. The higher socioeconomic status is, the lower level of stress the women feels during childbirth. Similar results were obtained by Błaszczak, Pilch and Szamlewska [18], who showed that housing conditions and employment have a significant impact on the level of anxiety in women in childbirth. The lowest level of anxiety and stress were tested with good and very good housing conditions and women with permanent jobs. Unemployed women with bad housing condition had significantly higher level of anxiety and stress. The Piech et al. [17] test results are convergent with our research results and also with Błaszczak, Pilch and Szamlewska's [18] test.

Kowalska et al. [14] in their study demonstrated that the number of previous births does not affect the level of stress, while the time of birth was important in the sense of stress and anxiety, because mothers of premature babies were more stressed than mothers of right term newborns. Libera also confirmed the results of the research regarding mothers of premature babies [19] and the related results represented in Mojs, Czarnecka-Iwańczuk and Głowacka' research [20], where women, who delivered preterm have significantly higher levels of anxiety and stress than women, who delivered newborns in right term. Our results are convergent with Kowalska J. et al. [14] relating to the lack of the effect of parity on the level of stress in childbirth.

Kowalska J. et al. [14] determined that the mood of women after childbirth was significantly correlated with the level of stress. The higher level of stress is, the worse feeling after birth occurs. It has been showed that the lowered stress level in the pregnancy ends by caesarean section. However, in our research, the level of stress in childbirth did not have any significant impact on the way of the pregnancy end.

To sum up, the results of research in almost every aspect confirm earlier reports of the scientific research field. The unmarried women having a low socioeconomic status, and those who delivered prematurely require special support from the medical staff in a hospital ward.

\section{CONCLUSION}

1. Women in childbirth are characterized by high level of stress.

2. Age, place of residence and education do not affect the stress level in women childbirth. Marital status and socioeconomic situation have an impact on the level of stress in childbirth. Unmarried women and those who have low 
socioeconomic status feel higher stress than married women, and those whose socioeconomic status is good or very good.

3. Date of birth determines the level of stress among women in childbirth. Women, whose pregnancies ended prematurely have a significantly higher level of stress than women who gave birth in right time. Number of births and way of birth do not determine the level of stress among women in childbirth.

\section{REFERENCES}

1. Hillerer KM, Neumann ID, Slattery DA. From Stress to Post-partum Mood and Anxiety Disorders: How Chronic Peripar-tum Stress Can Impair Maternal Adaptations. Neuroendocrinology. 2011;1-17.

2. Littleton HL, Bye K, Buck K, et al. Psychosocial stress during pregnancy and perinatal outcomes: A meta-analytic review. J Psychosom Obst Gyn. 2010;31(4):219-28.

3. Mitręga A. Matczyne debiuty. Obrazy doświadczania pierwszych tygodni macierzyństwa. Kultura - Społeczeństwo - Edukacja. 2014;1(5):55-72.

4. Gjerdingen D, Fontaine P, Crow S. Predictors of mothers' postpartum body dissatisfaction. Women and Health. 2009;49:491-504.

5. Sikorska M.: Nowy ojciec, nowa matka, nowe dziecko. Warszawa: Wydawnictwo Akademickie i Profesjonalne; 2010.

6. Czapiński J.: Strategie radzenia sobie z problemami i trudnościami (W:) Czapiński J, Panek T. Diagnoza Społeczna 2015. Warunki i jakość życia Polaków. Warszawa: Wyd. Contemporary Economics; 2015. p. 268-70.

7. Makara-Studzińska M, Zwierz K, Madej A, Wdowiak A. Sposoby radzenia sobie ze stresem kobiet we wczesnym połogu. J Public Health Nurs Med Rescue. 2015;4:38-43.

8. Walker LO, Xie B, Hendrickson SG, Sterling BS. Behavioral and psychosocial health of new mothers and associations with contextual factors and perceived health. J Obstet Gynecol Neonatal Nurs. 2016;45(1):3.

9. Cheng CY, Pickler RH. Perinatal stress, fatigue, depressive symptoms, and immune modulation in late pregnancy and one month postpartum. Scientific World Journal. 2014;65(2):63-70.

10. Rutkowska A, Rolińska A, Kwaśniewski W. Style radzenia sobie ze stresem u kobiet w ciąży prawidłowej i wysokiego ryzyka. Curr Probl Psychiatry. 2010;11(4):328-33.

11. Terelak J. :Rola wsparcia społecznego w radzeniu sobie ze stresem. Meritum. 2010;4:31-6.

12. Kossakowska K. Źródła wsparcia społecznego i wybrane sposoby radzenia sobie u kobiet z objawami depresji poporodowej. Probl Pielęg. 2012;20(3):310-6.

13. Kowalska J, Olszowa D, Markowska D, et al. Aktywność fizyczna i szkoła rodzenia w czasie ciąży a poziom postrzeganego stresu i objawów depresyjnych u kobiet po porodzie. Psychiatr Pol. 2014;48(5):889-900.

14. Chaaya M, Osman H, Naassan G, et al. Validation of the Arabic version of the Cohen perceived stress scale (PSS - 10) among pregnant and postpartum women. BMC Psychiatry 2010, 10: 111-118.

15. Juczyński Z, Ogińska-Bulik N. Skala Odczuwanego Stresu (PSS-10). In: Z. Juczyński, N. Ogińska-Bulik. (ed). Narzędzia Pomiaru Stresu i Radzenia Sobie ze Stresem. Warszawa: Pracownia Testów Psychologicznych; 2009. p.11-22.

16. Piech B. Wpływ warunków i stylu życia na poziom lęku kobiet w okresie połogu - badanie ankietowe. Prz Lek. 2017;74(3):101-5.

17. Błaszczak A, Pilch D, Szamlewska B. Badanie poziomu lęku kwestionariuszem STAI CD Spielbergera u kobiet w okresie okołoporodowym. Perinatol Neonatol Ginekol. 2011;4(3):163-8.

18. Libera A. Problemy psychologiczne okresu ciąży, Psychologiczne aspekty ciąży. In: M. Makara-Studzińska, G. Iwanowicz-Palus (ed). Psychologia w położnictwie i ginekologii. Warszawa: Wydawnictwo Lekarskie PZWL; 2009. p.154-7.

19. Mojs E, Czarnecka-Iwańczuk M, Głowacka MD. Poziom lęku jako stanu i jako cechy oraz depresji we wczesnym połogu - doniesienia wstępne. Psychiatr Pol. 2013;47(1):31-40.
Corresponding author

Dr hab. Artur Wdowiak

Medical University of Lublin

Diagnostic Techniques Unit

4-6 Staszica St., 20-081 Lublin

tel: +48 814486892

E-mail: wdowiakartur@gmail.com 